\title{
OPERATIONAL AND PROCEDURAL INTEGRITY OF ELECTIONS IN THE DEMOCRATIC REPUBLIC OF CONGO
}

\section{Tadjoudine Ali-Diabacté}

Tadjoudine Ali-Diabacté is a former lecturer-researcher at the University of Lomé, Togo and former Deputy Director of the UN Electoral Assistance Division

\begin{abstract}
Malpractice has affected the integrity of elections in the DRC in its three recent democratic electoral cycles: 2006, 2011, and 2018, particularly the last cycle. However, even though national and international media indicate that the degree of threats to electoral integrity is more critical in the DRC than the rest of Africa, the problems in the DRC are similar to those encountered in the rest of the continent. Moreover, in terms of election integrity the DRC may be better rated than many other African countries. This is particularly true of francophone Africa, as well as the Economic Community of Central African States (ECCAS) ${ }^{1}$ to which the DRC belongs. There are many good lessons learned from recent elections in the DRC which could inspire electoral authorities elsewhere in Africa and thus contribute to improving electoral integrity on the continent.
\end{abstract}

Keywords: electoral integrity, biometric voters' registration, manipulation of voting process, electoral conflict and violence, public confidence, parallel vote tabulation, publication of election results, electoral dispute resolution

\section{INTRODUCTION}

The purpose of this document is threefold: First, to present and review the operational and procedural integrity of elections. Second, to highlight some areas of malpractice which may have affected the integrity of the elections in the Democratic Republic of Congo (DRC) over its three most recent democratic

1 ECCAS has 11 Member States: Angola, Burundi, Cameroon, Central African Republic, Chad, Democratic Republic of Congo, Equatorial Guinea, Gabon, Republic of the Congo and São Tomé and Príncipe 
electoral cycles - 2006, 2011, and 2018 (with the focus on the last cycle). And third, to show that, even though national and international media portray the degree of threat to electoral integrity as being more critical in the DRC than the rest of Africa, the types of problems in the DRC are similar to those encountered in the rest of the continent. Moreover, in terms of election integrity the DRC can be better rated than many African countries, especially the francophone ones, as well as the Economic Community of Central African States (ECCAS) to which the DRC belongs. There are many good practices learned from recent elections in the DRC which could inspire African electoral authorities and thus contribute to improving electoral integrity on the continent.

This presentation is not the result of a formal study or survey conducted on the 2011-2018 DRC electoral cycle. Rather, it reflects knowledge arising from my contribution to the provision of international electoral assistance to the DRC since 2003.

The first part of this DRC case history is a description of some aspects of the electoral process that may have featured malpractice. This includes negative performance, evaluation, judgement and/or perception of the following components: the independence and capacity of the CENI (the Independent National Electoral Commission); the accuracy of the voter register; the compliance of the electoral calendar with the end of the electoral cycle; the regularities of the logistics and voting procedures; the conduct of the campaign; the acceptance of the results; and electoral violence.

The second part is the description of some factors that could pave the way for best practice and the integrity of the electoral cycle. This includes a positive analysis of the following elements: the legal framework; the autonomy and the capacity of CENI; the positive role played by political parties and civil society organisations (CSOs); and the funding of the electoral process. The third part is related to the weaknesses and strengths of the 'voting machine' in relation to the integrity of the 2018 elections.

Finally, the conclusion has a set of recommendations aiming at improving the integrity of the electoral processes in the DRC.

I hope this document, which focuses on the DRC's 2018 general elections, will stimulate thinking on the operational and procedural integrity of elections across Africa.

\section{OPERATIONAL AND PROCEDURAL INTEGRITY OF ELECTIONS}

There are many definitions of electoral integrity by politicians, academics, journalists and electoral institutes. But the common ground is an election that is transparent, free, impartial throughout the electoral cycle and based on international and democratic principles, good practice and agreements. Electoral 
integrity is a key ingredient to peace and stability, and integrity in elections depends on public confidence in all aspects of the electoral cycle. In Africa, especially since 1990, many electoral operations and procedures have been introduced into the electoral processes in order to reinforce public confidence in elections.

\section{Institutional Pre-requisites}

The following components constitute the essential institutional framework through which elections needed to be conducted:

- An independent and competent electoral management body (irrespective of whether this is organised by a government or is an independent electoral management body);

- Accurate voter registration: increasingly this involves the usage of biometric and electronic systems and machines to establish an accurate voters' roll;

- An audit of the voters' roll, which in ECCAS is usually undertaken by the Organisation Internationale de la Francophonie (OIF);

- Provisions for the public financing of party campaigning;

- Electoral system: in many emerging democracies a proportional system has been introduced as opposed to a winner-take-all system;

- Efficient and equitable boundary delimitation: this is particularly difficult when some of the population are nomadic, as in Mali where the Tuareg communities, comprising less than 2 percent of the population, live in the vast north of the country;

- Electoral calendar: combining elections (i.e. presidential, legislative and sometimes local elections) has become increasingly common.

\section{Confidence Building Measures during the Electoral Process}

Confidence-building measures include:

- Impartial registration of candidates and political parties;

- Media monitoring, televised debates for presidential candidates, use of social media platforms during campaigns;

- Voting operations: the use of single ballots or indelible ink, and electronic voting machines;

- Counting the ballots immediately after the polling, posting the results in polling stations and distributing copies of the tally sheets to representatives of candidates and political parties; 
- Transmission of results using technology such as VSAT and the internet;

- Parallel vote tabulation by observers and civil society organisations;

- Adjudication of electoral dispute by constitutional courts and electoral tribunals; also, by using modern technology and tally sheets provided in polling stations;

- Publication of results polling station by polling station, on social media, and on websites.

\section{Election Malpractice}

Election malpractice, as opposed to electoral integrity, consists of improper practices during an electoral process. In Africa, this includes:

- Manipulation of the electoral legal framework;

- Manipulation of the constitution (extension of presidential term limit), or of the electoral law;

- Manipulation of the voting process by intimidation, multiple voting, vote buying;

- Manipulation of the results (e.g. swapping the result of the winning candidate with that of the losing one), hacking servers and altering data and other electronic systems.

Electoral malpractice negatively impacts the legitimacy of the institutions and individuals thus elected. Malpractice can also lead to civil unrest and conflicts before, during and after elections.

\section{MALPRACTICE IN THE ELECTORAL PROCESS IN THE DRC}

Some areas of potential and actual malpractice in the DRC are as follows:

\section{The Composition and Management of the CENI}

The Independent National Electoral Commission (CENI) in the DRC, created by the Law No 13/12 of 19 April 2013, consists of 13 members appointed by political parties in the National Assembly, based on the proportions of the majority (six members) and opposition (four members) political parties respectively. Three members are appointed from the civil society, including representatives of NGOs involved in promoting the political participation of women, civic and voter education, and representatives of faith organisations. The Plenary, which is the 
steering board, consists of all 13 members of the CENI. The Bureau, which is the executive body, consists of six members including the president (civil society), the vice-president, (majority), the rapporteur (opposition), the deputy rapporteur (majority), the quaestor (majority) and the deputy quaestor (opposition).

The CENI and particularly its chairperson, Corneille Nangaa Yobeluo is generally perceived by many stakeholders as biased. There were allegations from national and international stakeholders on the shortcomings of the CENI as being a lack of independence, neutrality and transparency. Some of the members, accused of corruption, are currently under USA sanction.

\section{The Electoral Calendar and the Glissement ${ }^{2}$}

Kabila's second and last term was to end in 2016. But for technical and financial reasons the CENI planned the general elections for the end of 2018. This change was perceived by many observers as government manipulation of the electoral calendar to allow Kabila to stay in power for an additional two years.

\section{Voters' Registration and the Voters' Roll}

Over 40 million voters were registered by the CENI with the use of biometric registration kits. But in May 2018, following an audit of the voters' register, the $\mathrm{OIF}^{3}$ identified several technical irregularities that included multiple registrations and duplicate voters' cards (6 million), registration of young people under the age of 18, and registrations without ID cards or witnesses. Another concern in this report was the fact 16.6 percent of all enrollees had no fingerprints. The report also noted that 94 percent of enrollees without fingerprints were registered in the ruling party stronghold, Sankuru and Tshuapa. In the meantime, some violence was noted in the opposition strongholds, Kassai, Central Kassai and Lomani provinces. The voters' lists were not made available to the public on time ( 30 days before the polls to allow for possible legal challenge). There was also an issue about the transparency of the international tender for the procurement of the voter registration material won by GEMALTO.

\section{Registration of Candidates and Voting Procedures}

The two main opposition candidates for the presidential election, Jean-Pierre Bemba and Moise Katumbi, saw their applications rejected: the first due to his

2 In the DRC context this French term indicates intentional delay in the electoral calendar.

3 OIF : Audit du fichier électoral national de la République démocratique du Congo, Rapport final, mai 2018 
indictment by the International Criminal Court (ICC), and the second condemned by a DRC court. In addition, a few months before the registration process of candidates and parties, and the polls, the National Assembly passed a new electoral law with two new provisions: i) parties should have a representation threshold to be registered, ii) the vote could be manual or electronic. Also, the amount of the candidate's deposit was increased for all the polls. These measures were interpreted by some observers as an attempt to limit opposition participation in the elections.

\section{Security of the Process, Freedom of the Media and the Right to Protest}

On 13 December a warehouse fire destroyed over 8000 voting machines as well as electoral materials. Despite speculation about who the perpetrators might be, they have still not been found. As a consequence the general elections were postponed from 23 December to 30 December 2018.

Although campaigning was generally peaceful, there was violence with loss of life in Kalemie, Lubumbashi and Mbuji-Mayi.

Elections were postponed in Beni, Butembo and Yumbi, officially because of the Ebola virus and lack of security in the region. Given that these regions are considered to be strongholds of the opposition, some stakeholders alleged that there was an attempt by the government and the CENI to prevent opposition voters from exercising their right to vote in those areas.

Acts of intimidation were also noted in press reports, though the media in question were shut down and journalists arrested. Some observer missions noted unequal access to state media coverage. Freedom of assembly and the right to demonstrate were limited by the police and the armed forces at various stages of the electoral cycle.

\section{Tabulation and Announcement of the Results by the CENI}

Vote counting began immediately at the polling stations. However, it took many days for the centralisation, tabulation and announcement of the results, and the announcement was highly controversial. First, the results had not been published polling station by polling station, as they should have been. Secondly, there was a sharp discrepancy between the presidential results published by the CENI and the results from the parallel counting of the Catholic Church (40 000 observers using $72 \%$ of the tally sheets). According to the National Episcopal Conference of Congo (CENCO) the winner of the presidential elections was not Felix Tshisekedi (France24.com). This position was backed by some members of the international community. Moreover, Martin Madidi Fayulu, one of the opposition presidential candidates, claimed the victory. He also called for a manual recount of the votes. 
The results of the 2018 general elections were rejected by the losers at both presidential and National Assembly levels.

\section{Electoral Dispute and Resolution}

The Constitutional Court is in charge of electoral disputes and the announcement of the final results for presidential and legislative elections. Its nine members are appointed by presidential decree from individuals designated by the Parliament, the Superior Council of Magistrates and the head of state. There is a perception by many stakeholders of bias in the Constitutional Court, and particularly in its president Benoit Lwamba Bindu. The court's decision confirmed the contested presidential results announced by the CENI: Felix Tshisekedi (UDPS) 38.6\%; Martin Fayulu (LAMUKA) 34.8\%; Emmanuel Ramazani (FCC) 23.8\%. The same applied to the elections of members of parliament. Most of the appeals were rejected and parties supporting President Kabila won the majority of seats in the National Assembly.

\section{Conclusion}

The examples listed above indicate that the DRC's 2018 general elections were not a good example of integrity across most of these three dimensions of its electoral cycle:

- agents (lack of freedom of media, impeded freedom of assembly and of the right to demonstrate);

- political bias (lack of independence of both the CENI and the Constitutional Court, inaccuracy of the voters' roll);

- outcome (irregularities in the tabulation and announcement of the results, electoral violence in some regions, non-acceptance of the results at all levels).

\section{INTEGRITY IN THE ELECTORAL PROCESS OF THE DRC}

However, there are many other aspects of the DRC elections which comply with national and international good practice and election regulations. Listed below are some of these factors.

\section{The Legal Framework}

The DRC Constitution provides for universal, equal, secret and direct suffrage, provincial and local institutions, the right of political parties to exist and 
participate in elections, freedom of expression and the right to protest. The Constitution assures the regularity of elections. More importantly, and differently from many francophone African countries, there is a provision for a term limit for presidential and legislative positions, and there is also the option for the diaspora to vote.

\section{The Autonomy of the CENI}

Despite the alleged malpractice of some of its members, the CENI has more management and financial autonomy than the EMBs (election management bodies) of many African countries. CENI is fully in charge of the administration of the elections, including voter registration, calendar, boundary delimitation, the elections, and the announcement of preliminary results. In many African countries, most electoral tasks are carried out by the government despite the existence of a so-called independent EMB. In addition, the structure and the mandate of the CENI are in accordance with the South African Development Community $(\mathrm{SADC})^{4}$ Principles and Guidance Governing Democratic Elections.

\section{The Capacity of the CENI}

During the 2018 electoral cycle, the CENI managed the following challenges in a professional manner:

- logistics (2345 $000 \mathrm{~km}^{2}$ without infrastructure and without the support of the international community donors and MONUSCO (The United Nations Organization Stabilization Mission in the Democratic Republic of the Congo);

- registration of over 40 million voters;

- over 512000 electoral agents;

- 75500 polling stations;

- 21 candidates for presidential elections; 15355 candidates for the National Assembly;

- 19640 candidates for the Provincial Assembly.

Beside its Plenary and Bureau, the CENI has one of most experienced and competent electoral technique components on the continent. Most of its members (including Chairperson Corneille Nangaa Yobeluo and the current Chief of Operations) have been on duty since 2004, during which time they have accumulated appropriate knowledge and competence. The National Executive

4 DRC is also member of SADC 
Secretariat (NES) and its National Bureau of Operations (NBO) are among the most structured and best-equipped technical electoral structures in Africa.

\section{Biometric Voter Registration}

Voter registration is among key aspects that determine the integrity of an electoral process. This is particularly sensitive in the DRC, as the country has not had a general census since 1984 and does not have a good civil register in place. The voters' roll also serves as the basis of boundary delimitation, and the voters' card is the de facto national ID card. Despite the shortcomings noted above regarding the voter registration process, the biometric voter registration, started in 2004 in the DRC, is strong enough to mitigate fraud and build confidence in the electoral process. A total of 22000 biometric kits were used to register over 40 million voters nationwide.

\section{The Role of Political Parties}

Over the past 20 years, political parties have strengthened their capacity to mobilise. Despite their huge number (over 600 parties), they have managed to form three main and active coalitions: the Common Front for Congo (FCC) led by Kabila; the Thsisekedi-Kamerhe coalition, Cap for the Change (CACH); and the Bemba-Katumbi-Fayulu coalition (LAMUKA) which has no clear leader. The parties have also managed to form a coalition CACH-FCC to rule the country peacefully. Despite the controversy surrounding the use of the voting machine, the alleged bias of both the CENI and the Constitutional Court, and many restrictions of freedom, DRC political parties did not call for a boycott of the 2018 general elections.

\section{The Role of Civil Society Organisations and Media}

Civil society organisations played a tremendous role in the 2018 general elections in voter education, media campaigns, and domestic observation, among others. Together with political parties and members of the international community, CSOs prevented Kabila from amending the Constitution in 2015 in order to extend the presidential term limit. Organisations such as Fight for Change (LUCHA), Women Synergy (SF) and many other CSOs were active, and created a check and balance dynamic during the electoral process. CENCO (the Catholic Episcopal Church of Congo) played a key role in the dialogue process, in domestic observation as well as the parallel vote tabulation (PVT) of the votes. As a result, there were good turnouts as well as peaceful conduct at the polls on election day. 


\section{Funding the Electoral Process}

The budget for the 2018 general election was over 2 billion USD, including the cost of political dialogue, voter registration and the polls. In order to preserve the country's sovereignty, the government decided to fully fund the electoral process. This position is also in line with the AU Principles on Elections. In 2006, the Panel of the Wise had determined, and this has been subsequently reaffirmed, that all African countries shall fund their electoral processes through their national budget.

\section{Conclusion}

The factors described above indicate that some aspects of the DRC elections could be considered as good practice, in accordance with CEMAC, SADC, ECOWAS, $\mathrm{AU}$ and other international principles regarding good election practice aimed at ensuring the integrity of the elections.

\section{THE VOTING MACHINE ${ }^{5}$}

The electoral commission introduced e-voting machines prior to the elections in December 2018. There were initial concerns that there was inadequate voter education, that the system was untried and that the machines could be manipulated to rig the election. However, their use appears to have strengthened the integrity of the electoral process.

In the case of the DRC, the voting machines served in effect as printers. Rather than manually completing a pre-existing ballot paper, the voter makes their choice on a screen and after this is completed, the machine prints a copy of this choice which the voter then deposits in a ballot box. The use of the machine enables electronic as well as manual vote counting and eliminates the need for printing and distributing ballot papers, enabling considerable savings in transport costs. Article 47, paragraph 1 of the Electoral Law, 2016, states that 'The vote can be carried out either by a paper ballot or electronically'. The Political Agreement of 31 December 2016 (Art. 4, paragraph 4) recommends that the government 'explore ways and means to streamline the electoral system in order to reduce the excessively high costs of elections'. The machines' proposed deployment in the 2018 elections evoked mistrust from voters and political leaders, as well as among the international community. The voting machine was called a 'fraud machine' intentionally introduced by the CENI to favour the ruling party. Some arguments against the voting machine are:

5 Sources: CENI and UN presentations on the voting machine 
- No political consensus on the use of the machine;

- Risk of computer hacking or manipulation of results which may impact the integrity of the results transmitted from the voting machine;

- Risk of discrepancy between the published trends and the provisional results, which would lead to a post-election crisis;

- Voting machine not yet tested in any prior election in the DRC;

- High illiteracy rate especially in the rural areas, resulting in the issue of voter assistance to cast ballots;

- Availability of qualified technicians to be recruited locally to manage 23000 polling centers;

- Insufficient number of backup machines per polling centre, to substitute in case of breakdown;

- Elections conducted on one day only, thus any technical problem, however minor, could lead to protests and in turn cancel the election;

- International community concern that the machine was conceived in the DRC and manufactured in South Korea, and not in a western country as was usual.

\section{Conclusion}

There was initial mistrust for the voting machine because of the political conditions in which it was introduced. In practice, however, the machines seemed to have worked efficiently and despite initial misgivings were not used to manipulate the count, as accidently released electronic tally sheets made perfectly evident.

After the 2018 experience the voting machine appears to be a tool that can strengthen the integrity of the electoral process in the following ways: by reducing fraud, reducing the weight and costs of logistics (i.e. production and transportation of ballot papers), reinforcing the confidence in the vote counted twice (electronically and manually), reducing the time for the transmission of results from polling centres to centralisation centres, and providing enough copies of the tally sheets for all the candidates' representatives and the domestic observers.

\section{CONCLUSION}

Measures to Improve Operational and Procedural Integrity of the Electoral Process in the DRC

Generally, the 2018 electoral cycle featured significant improvements in electoral administration. As the foregoing analysis suggests, the major flaws were located 
at the apex of the system in the top leadership of CENI and of the Constitutional Court, both of which were complicit in falsifying the final results. If in future the DRC is to hold elections of high integrity, major political reforms are needed to protect CENI and the Constitutional Court and reduce their susceptibility to political bias.

At present, DRC has achieved impressive levels of electoral administrative capacity. Even so, more effort is needed in the following areas:

\section{Stakeholder Consultation by the CENI}

There are already consultation frameworks between the CENI and key national stakeholders - political parties, CSOs and national institutions; and between the CENI and the international community - the coordination mechanism of the UN with a strategic committee, steering committee, technical committee, etc. But the CENI needs to strengthen its communication strategy, especially on new operations like biometric voter registration and the use of the voting machine.

\section{General Census and Civil Registry}

The DRC spends billions of USD annually to update its voters' roll. The government and the CENI should explore the following possibilities, four years before the general elections:

- Conduct a general census of the population as the last was held in 1984. An updated census will provide data for many different applications as well as accurate boundary delimitation.

- Conduct civil registration to provide all citizens with biometric ID cards that could also serve various purposes, including polling.

\section{Improvement of the Voting Machine}

National authorities may consider improving the voting machine in the following ways:

- By improving both hardware and software (updates);

- By intensifying the sensitisation of the population to its importance and its use.

\section{Funding the Electoral Process}

The government has funded mainly voter registration and electoral operations. The authorities may consider expanding this to include the following improvements:

- Funding political parties;

- Funding electoral campaigns;

- Funding civil society organisations involved in the elections. 
To avoid the recurrent post-election crisis on the continent, particularly in francophone countries, Africa needs models of electoral frameworks and good practice that can guarantee the integrity of the elections. I invite election practitioners to look carefully and dispassionately at the electoral system of the DRC. Despite occasional malpractice related mainly to individuals rather than the system, there are some good lessons to be learnt from the DRC electoral system and adapted to many other countries. These include: the independence and attributes of the electoral commission (CENI); government funding of the elections from the national budget; and the use of voting machines with locally manufactured software designed for African needs. The new election integrity paradigms in Africa will come from within the continent. But political will is the key factor.

\section{Acknowledgement}

This paper was presented at the $14^{\text {th }}$ EISA Annual Symposium, Johannesburg, 25 September 2019.

ACE 2016, Biometric voter Registration and Voter Identification. (Available at: http: / / aceproject.org/electoral-advice/)

African Union 2019, Preliminary Statement of the African Union Electoral Observation Mission to the 2018 Democratic Republic of the Congo Presidential, Legislative and Provincial Elections, Kinshasa.

African Union 2000, Constitutive Act of the African Union, Addis Ababa.

African Union 2002, African Union Declaration on the Principles Governing Democratic Elections in Africa, Durban.

African Union 2007, African Charter on Democracy, Elections and Governance, Addis Ababa.

CENI 2016, Legal Provision for illiterate voters, [Independent National Electoral Commission, Kinshasa]

Congo (Democratic Republic) 2011, Constitution of 2005 with amendments.

Congo (Democratic Republic) 2016, Electoral Law 2014 as amended in 2016.

Congo (Democratic Republic) 2016, Law No 04/028 of December 24/2004, identifying and enlisting voters in the Democratic Republic of the Congo, as amended and supplemented by Law No 16/007 of June 29, 2016.

Congo (Democratic Republic) 2017, Law No 06/006 of March 9, 2006, Carrying Organisation of the Presidential, Legislative, Provincial, Urban, Municipal and Local elections, as modified by the Law No 17/013 of December 24, 2017. 
Dunia P, Zongwe, FB \& Mavungu, PC 2015, Update: the legal system of the Democratic Republic of the Congo (DRC), Overview and Research, (Available at https: / / www.france24.com/en/20190110-dr-congo-catholic-church-election-tallydifferent-winner-tshisekedi-fayulu)

MONUSCO \& UNEAD: Reports on the DRC elections in 2016-2018.

SADC 1992, Principles and Guidance Governing Democratic Elections, Windhoek.

SADC 2018, Preliminary Statement of SADC Electoral Observation Mission (SADCEOM) to the 2018 Democratic Republic of the Congo Presidential, Legislative and Provincial Elections.

UNDP 2016, Electoral Cycle Assistance Project (PACE), Kinshasa. 